\title{
ANALYSIS OF GIS HIGHER EDUCATION IN CHINA
}

\author{
Liu Yaolin Shen Yuanchun \\ School of Resource and Environmental Science, Wuhan University, \\ Wuhan City (430079),P.R. China \\ (yaolib610@163.com)
}

KEY WORDS: GIS Higher Education, Distribution, Curriculum, Enrolment, Graduation, Employment

\begin{abstract}
:
The first GIS Bachelor's Program arose in China in 1980s. After more than 30 years of exploration and practice, it is now in the period of full-scale development. The paper collects the data of the number and spatial distribution of colleges and universities with GIS specialty in China. After that it makes comparative analysis of GIS curriculum of three typical universities. Then on the base of data of enrolment and employment in Wuhan University, it discusses the classification of enrolments and graduates and emphasis on the industrial and regional distribution of the graduates. Through the above investigation and analysis, the paper finally draws the conclusion on the features and problems in China's GIS higher education.
\end{abstract}

\section{INSTUCTION}

With the advent of the Canadian Land Information System in 1960s, GIS theory, methodology and applications have constructed and developed rapidly in North America. It was introduced into China in 1980s. With the first GIS Bachelor's degree program appeared in Wuhan Technical University of Surveying and Mapping in 1988 and the first GIS Master's degree program in Wuhan in 1993, the GIS higher education has drawn the curtain. Accompanied by the developing of GIS technology and the increasing demand of the society, the Ministry of Education added two second-level subjects "Cartography and Geographic Information Systems" and "Cartography and Geographic Information Engineering", which are subordinate to the first-level subjects "geography" and "surveying and mapping " respectively, to the specialty catalogue for postgraduates in 1997. After that the specialty of Geographic Information System (GIS) was officially added into specialty catalogue for undergraduates in 1998. It means that a complete GIS higher education system, including undergraduates, postgraduates, doctoral students, post-doctors and international students, has been formed in the end of last century, which has laid a solid foundation for the prosperity in the new century (Bian Fuling, 2004). The "Geographic Information System" was officially renamed "Geographic Information Science" in the documents of "Undergraduate catalogue" and "The regulations of setting specialty catalogue for undergraduates" (Teach High [2012] No. 9) released by the Ministry of Education in 2012. Since 2013, all colleges and universities began to enrol with the new specialty name.
The GIS education in Wuhan University, which evolved from surveying and mapping specialty in former Wuhan Technical University of Surveying and Mapping, reflects the process of GIS education in China on the whole. The paper, based on analysing GIS education in Wuhan University, and combined with relevant circumstances of other colleges and universities, try to discuss the present GIS higher education in China in aspects of specialty distribution, curriculum, enrolment and employment, and make analysis on the issues of GIS teaching and talents training on the basis of that.

\section{DATA COLLECTION AND DISCUSSION}

\subsection{Distribution of GIS Colleges and Universities}

A large number of colleges and universities have established GIS specialty since 1990s. According to statistics, GIS degree program was offered in 37 colleges and universities in 2000, and the number increased to 93 in 2003 (Qin Qiming, 2011). According to the latest statistics (2013 enrolment plan) on the website of the Ministry of Education, there are 161 colleges and universities with GIS specialty(excluding military academy and the universities in Hong Kong, Macao and Taiwan), which covers the most provinces of the country. Figures 1, 2 and 3 show the number of GIS colleges and universities in the provinces and cities at different education levels respectively. 


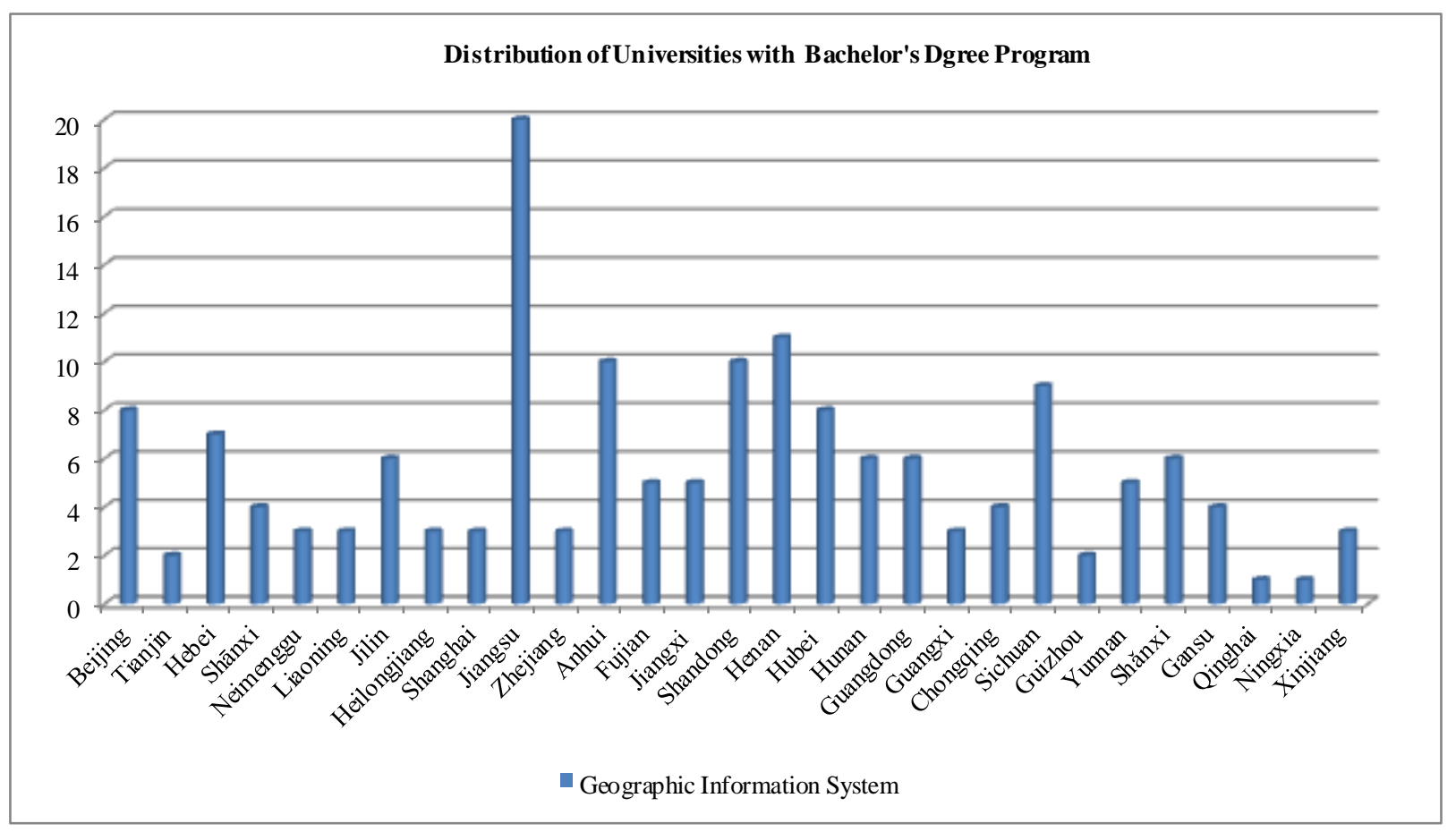

Figure 1. Distribution of Universities with Bachelor's Degree Program

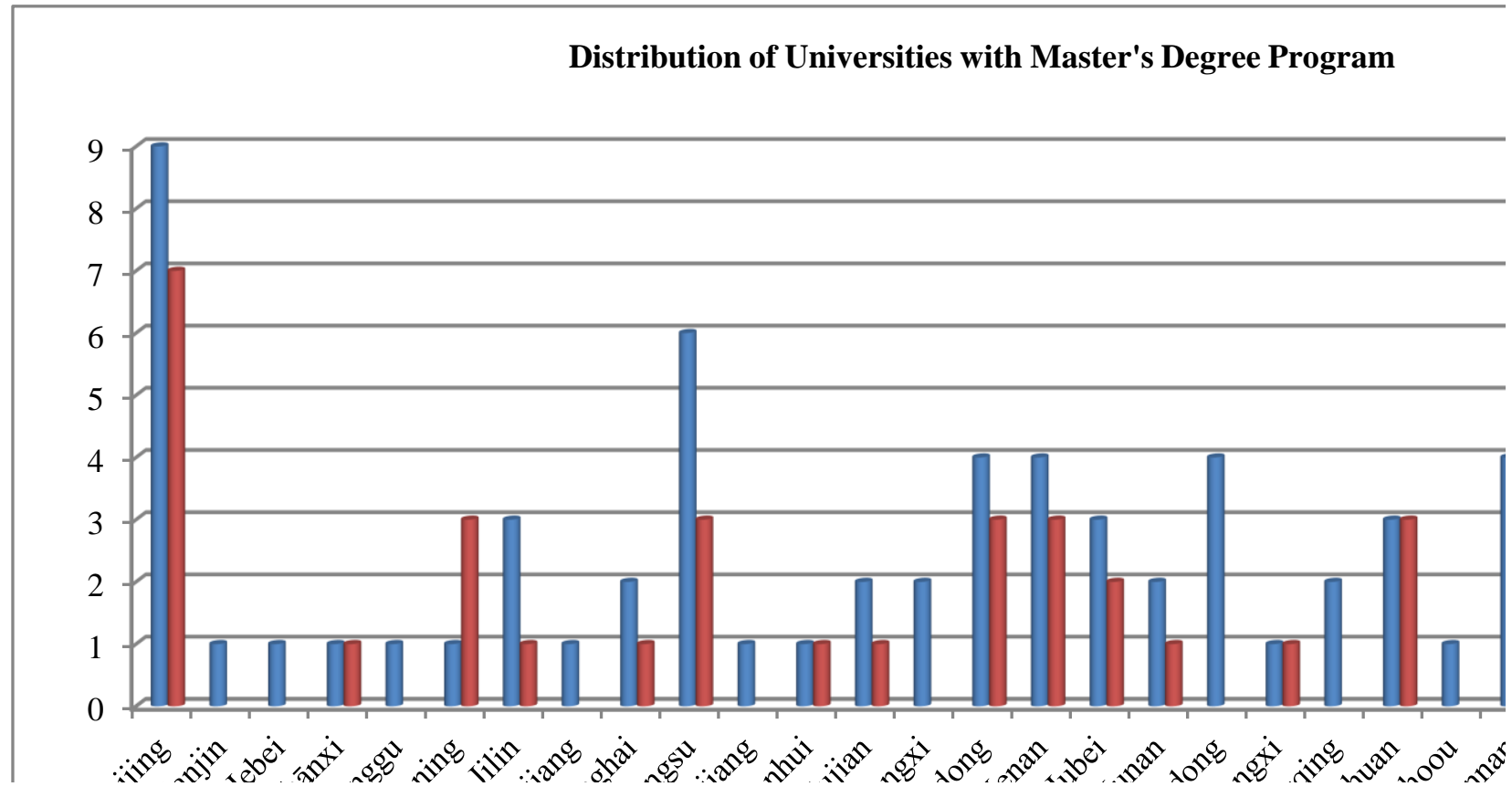

Figure 2. Distribution of Universities with Master's Degree Program 


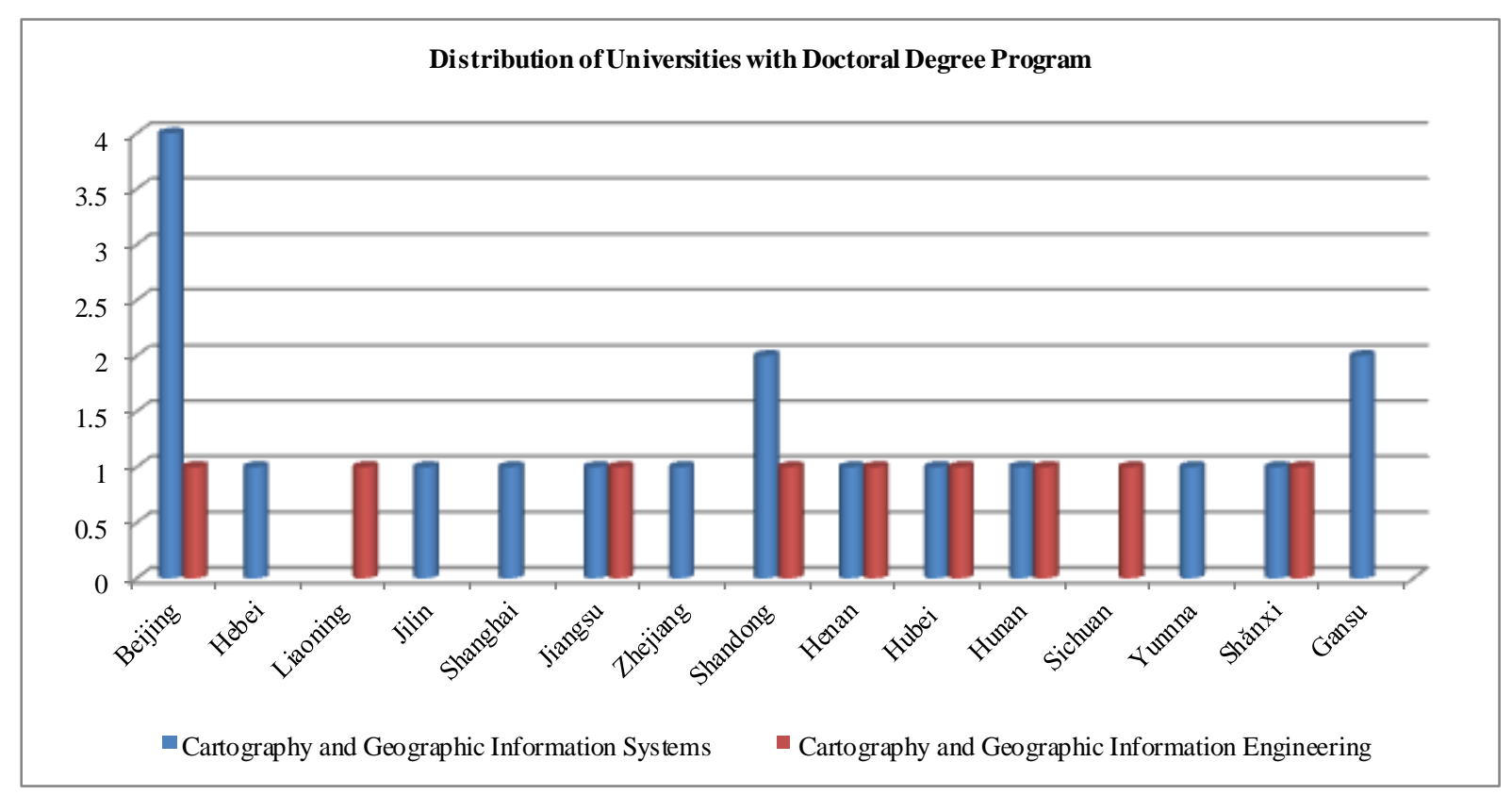

Figure 3. Distribution of Universities with Doctoral Degree Program

From the view of numbers, there are 161 colleges and universities in 29 provinces and cities that set up undergraduate specialty of GIS. 74 universities and research institutes in 29 provinces and cities offer master's degree program of cartography and geographic information system, and 34 universities and research institutes in 16 provinces and cities offer master's degree program of cartography and geographic information engineering. There are 18 universities and research institutes in 13 provinces and cities offering doctoral degree program for cartography and geographic information system and 9 universities or research institutes in 9 provinces and cities offering doctoral degree program for cartography and geographic information engineering.

From the view of spatial distribution, there are 20 colleges and universities with GIS specialty in Jiangsu, which is the largest number. Both Ningxia and Qinghai has one university with GIS specialty. Tibet and Hainan have not yet opened university with GIS specialty. From the view of located cities, the top 3 city with GIS universities are Nanjing, Beijing and Wuhan. On the whole, more GIS universities are in East, Central, North and Southwest, and less are in Northeast, South and Northwest.

From the view of university's type, 42 are "211 University", which include 14 "985 University". There are 31 universities opened by central department, which are subordinate to the Ministry of Education, the Ministry of Transportation and the Ministry of Industry and Information Technology. From the view of school's level, there are 117 universities, 31 colleges, 12 independent colleges and 1 advanced professional school. And all GIS universities can be found in the following classification: comprehensive (42), normal (46), engineering (51), agriculture (13), forestry (13), and finance (3). In addition, there are 2 military universities and 8 research institutes at the postgraduate's and doctoral stage.

Thus it can be seen two features in our GIS education development: The first is the rapid development and enlargement promoted by social needs. The colleges and universities, covering all types, at all levels and in different categories of Chinese higher education, burst into bloom in the 16 years enrolment from 1998 to 2013, showing a diversified, layered and large-scale developed pattern (Qin Qiming, 2011). The second is the uneven distribution due to the historical and economic factors. As GIS education in China has different origins, the stronger the geography, surveying and mapping or computer subjects are, the better the universities with GIS specialty developed. It now formed three teaching centres: Wuhan, Nanjing and Beijing. Besides, the areas with flourishing economy and high degree of information, such as East and North, for the stronger teaching conditions and better teachers, are superior to the weaker areas.

\subsection{The Features of GIS Curriculum and Talents Training}

The GIS core courses are generally divided into four modules: geography, surveying \& mapping and remote sensing, computer and GIS courses (Bian Fuling, 2007). The paper make a comparison between the universities with different supported subjects which are selected from the three teaching centres in China, as shown in Table 1 and Table 2, where the data comes mainly from the latest teaching materials and the official websites of the universities. The supported subjects in Wuhan University and Nanjing University represent respectively the two traditional academic systems in GIS field - surveying \& mapping and geography, and the supported subject in China University of Geosciences (Beijing) represents the new technology joining the field - computer. 
Table 1. Summary of GIS Specialty in Wuhan University, Nanjing University and China University of Geosciences (Beijing)

\begin{tabular}{|c|c|c|c|c|c|}
\hline University & School & $\begin{array}{l}\text { Supported } \\
\text { Subject }\end{array}$ & $\begin{array}{l}\text { Master's Degree } \\
\text { Program }\end{array}$ & $\begin{array}{l}\text { Doctoral Degree } \\
\text { Program }\end{array}$ & $\begin{array}{l}\text { International } \\
\text { Joint Training } \\
\text { Program }\end{array}$ \\
\hline Wuhan University & $\begin{array}{l}\text { School of Resource } \\
\text { and Environmental } \\
\text { Sciences }\end{array}$ & $\begin{array}{l}\text { Surveying } \\
\text { and Mapping }\end{array}$ & $\begin{array}{l}\text { Cartography and } \\
\text { Geographic } \\
\text { Information System, } \\
\text { Cartography and } \\
\text { Geographic } \\
\text { Information } \\
\text { Engineering }\end{array}$ & $\begin{array}{l}\text { Cartography and } \\
\text { Geographic Information } \\
\text { System, Cartography and } \\
\text { Geographic Information } \\
\text { Engineering }\end{array}$ & $\begin{array}{l}\text { "2+2" Program } \\
\text { with Waterloo } \\
\text { University in } \\
\text { Canada, } \\
\text { " } 2+2 " \text { Program } \\
\text { with Newcastle } \\
\text { University in } \\
\text { England }\end{array}$ \\
\hline Nanjing University & $\begin{array}{l}\text { School of Geographic } \\
\text { and Oceanographic } \\
\text { Sciences }\end{array}$ & Geography & $\begin{array}{l}\text { Cartography and } \\
\text { Geographic } \\
\text { Information System }\end{array}$ & $\begin{array}{l}\text { Cartography and } \\
\text { Geographic Information } \\
\text { System }\end{array}$ & \\
\hline $\begin{array}{l}\text { China University of } \\
\text { Geosciences(Beijing) }\end{array}$ & $\begin{array}{l}\text { Information } \\
\text { Engineering College }\end{array}$ & $\begin{array}{l}\text { Computer } \\
\text { Science and } \\
\text { Technology }\end{array}$ & & $\begin{array}{l}\text { Cartography and } \\
\text { Geographic Information } \\
\text { System }\end{array}$ & $\begin{array}{l}\text { "2+2" Program } \\
\text { with Waterloo } \\
\text { University in } \\
\text { Canada }\end{array}$ \\
\hline
\end{tabular}

Table 2. GIS Core Courses in Wuhan University, Nanjing University and China University of Geosciences (Beijing)

\begin{tabular}{|c|c|c|c|}
\hline University & Module & Course Name & Practical Teaching \\
\hline \multirow[t]{4}{*}{ Wuhan University } & Geography & Physical geography, Geomorphology & Comprehensive practice of Geography \\
\hline & $\begin{array}{l}\text { Surveying and } \\
\text { Remote Sensing }\end{array}$ & $\begin{array}{l}\text { Introduction of Surveying and Mapping, Digital } \\
\text { Mapping and GPS, Remote Sensing and Its Application, } \\
\text { Map Projection Transformation, Map Design and } \\
\text { Compilation }\end{array}$ & $\begin{array}{l}\text { Practice of Digital Mapping and GPS, } \\
\text { Practice of Remote Sensing and Its } \\
\text { Application, Practice of Map Design } \\
\text { and Compilation }\end{array}$ \\
\hline & Computer & $\begin{array}{l}\text { C Programming Language, Database Technology, Data } \\
\text { Structure }\end{array}$ & \\
\hline & GIS courses & $\begin{array}{l}\text { GIS Principle and Application, Object Oriented } \\
\text { Programming of GIS, Fundamentals of GIS Graphics } \\
\text { Algorithm, Principles of Spatial Database, Geospatial } \\
\text { Data Processing, Spatial Analysis and Geo Statistics, GIS } \\
\text { Engineering Design, Visualization of Spatial } \\
\text { Information, Development of GIS Software, WebGIS and } \\
\text { Geographic Information Service }\end{array}$ & $\begin{array}{l}\text { Practice of WebGIS and Geographic } \\
\text { Information Service, Practice of GIS, } \\
\text { Graduation Thesis or Design }\end{array}$ \\
\hline \multirow[t]{4}{*}{ Nanjing University } & Geography & $\begin{array}{l}\text { General Geology, Physical Geography, Human } \\
\text { Geography, Economic Geography, Geographic Modeling, } \\
\text { Introduction of City and Regional Planning }\end{array}$ & $\begin{array}{l}\text { Teaching Practice of Geology, } \\
\text { Teaching Practice of Geography }\end{array}$ \\
\hline & $\begin{array}{l}\text { Surveying and } \\
\text { Remote Sensing }\end{array}$ & $\begin{array}{l}\text { Digital Photogrammetry, Surveying and Cartography, } \\
\text { Remote Sensing Theory, Map Projection, Map design } \\
\text { and Making, Digital Map }\end{array}$ & \\
\hline & Computer & $\begin{array}{l}\text { C Programming Language, Fundamentals of Computer } \\
\text { Application }\end{array}$ & \\
\hline & GIS courses & $\begin{array}{l}\text { GIS Introduction, GIS Theory, GIS Design, Digital } \\
\text { Terrain Model, Digital Image Processing, Lectures on } \\
\text { GIS }\end{array}$ & Social Practice, Graduation Practice \\
\hline \multirow{4}{*}{$\begin{array}{l}\text { China University of } \\
\text { Geosciences(Beijing) }\end{array}$} & Geography & Geography, City Planning & Geography Practice \\
\hline & $\begin{array}{l}\text { Surveying and } \\
\text { Remote Sensing }\end{array}$ & $\begin{array}{l}\text { GPS Principle and Application, Remote Sensing Theory, } \\
\text { Remote Sensed Image Processing, Geo Application of } \\
\text { Remote Sensing }\end{array}$ & $\begin{array}{l}\text { Cartography Practice, Practice of } \\
\text { Remote Sensed Image Processing }\end{array}$ \\
\hline & Computer & $\begin{array}{l}\text { Computer Programming, Computer Graphics, Data } \\
\text { Structure, Computer Network }\end{array}$ & $\begin{array}{l}\text { Practice of Computer Graphics, } \\
\text { Practice of Data Structure }\end{array}$ \\
\hline & GIS courses & $\begin{array}{l}\text { GIS Principle and Method, GIS Design and Application, } \\
\text { GIS Software Engineering, Spatial Database, } \\
\text { Development of GIS Application System, Spatial } \\
\text { Analysis of GIS, WebGIS Technology }\end{array}$ & $\begin{array}{l}\text { Practice of GIS Software, Practice of } \\
\text { Spatial Database, Practice of } \\
\text { professional GIS Design and } \\
\text { Application, Practice of GIS in } \\
\text { Sections and its Application, Practice } \\
\text { of GIS Software Engineering, Practice } \\
\text { of GIS Application System } \\
\text { Development, Graduation Thesis }\end{array}$ \\
\hline
\end{tabular}

According to the above four knowledge modules, we count the course numbers and the proportion of every module in the whole, in the following Table 3. 
Table 3. Structure of GIS Core Course in Wuhan University, Nanjing University and China University of Geosciences (Beijing)

\begin{tabular}{|c|c|c|c|c|c|c|c|c|}
\hline & \multicolumn{2}{|c|}{ Geography } & \multicolumn{2}{|c|}{ Surveying and Remote Sensing } & \multicolumn{2}{|c|}{ Computer } & \multicolumn{2}{|c|}{ GIS courses } \\
\hline & $\begin{array}{l}\text { Courses } \\
\text { Number }\end{array}$ & Proportion & $\begin{array}{l}\text { Courses } \\
\text { Number }\end{array}$ & Proportion & $\begin{array}{l}\text { Courses } \\
\text { Number }\end{array}$ & Proportion & $\begin{array}{l}\text { Course } \\
\text { Number }\end{array}$ & Proportion \\
\hline Wuhan University & 4 & $14.81 \%$ & 8 & $29.63 \%$ & 3 & $11.11 \%$ & 12 & $44.44 \%$ \\
\hline Nanjing University & 8 & $34.18 \%$ & 6 & $26.09 \%$ & 2 & $8.69 \%$ & 7 & $30.43 \%$ \\
\hline $\begin{array}{l}\text { China University of } \\
\text { Geosciences(Beijing) }\end{array}$ & 3 & $10.34 \%$ & 7 & $26.08 \%$ & 6 & $20.68 \%$ & 13 & $44.83 \%$ \\
\hline
\end{tabular}

The data tells us that the key module is different with different supported subject, teaching system and science research direction. For instance, the number and percentage of courses of mapping and remote sensing in Wuhan University is higher than other two universities. Nanjing University put its emphasis on geography. And there are much more Computer courses in China University of Geosciences (Beijing).

Wuhan University represents the GIS universities with surveying and mapping background. The surveying and mapping specialty, which was the earliest established in the former Wuhan Technical University of Surveying and Mapping, is the strongest in China. Based on the cartography origin, the core courses put stress on surveying, mapping and remote sensing, emphasizing the ability of data acquisition and processing. It pays more attention to students' practical ability training through the practical courses, corresponding to the theoretical courses of the same name, and also through the large credit hours of computer practice of many class studies. So the GIS specialty is an engineering-oriented science in our university.

Nanjing University represents the GIS universities with geography background. It is one of China's earliest university established the Department of Geography. Owing to its geography advantage, the core courses of GIS put geography in the first place, which take GIS as a tool to understand and analyze the natural and human phenomena and space-time evolvement rules, emphasizing on the knowledge of man-land relationship. As a result, the students learn more theoretical courses and less practical courses.

China University of Geosciences (Beijing) represents the GIS universities with computer science and technology background. The Information Engineering College, which the GIS specialty belongs to, grew out of the Department of Computer Application. So the core courses stress on computer and GIS software applications. Students are required to have higher computer capability and learn a lot of practical courses on software development and applications.

Overall, our GIS curriculum has the following characteristics: The first is the subject integration. No matter what the background is, the GIS core courses are related to geography, surveying and mapping, computer and GIS courses, which form the theoretical and technical foundation of GIS education, and select GIS professional courses as the key module. Second, there is on unified core course system but various according to their heritage. The third is the international trends. With the development of international exchanges and cooperation, the joint training program is increasing. Through the learning from foreign advanced achievements, our GIS curriculum has make progress gradually.

\subsection{Investigation on Enrolment and Employment of GIS} Specialty in Wuhan University

The paper collects the data of enrolments and graduates of GIS specialty, in the stage of undergraduates, postgraduates and doctoral students, of Wuhan University in recent ten years, as shown in Table 4 and 5 . Then it focuses on discussing the graduates with Bachelor's Degree in terms of classification of graduates, the industrial distribution and spatial distribution of the employers in their graduated year.

\subsubsection{The Number of Enrolments and Graduates of GIS Specialty}

Table 4. 2004-2013 the Number of GIS Enrollments in Wuhan University

\begin{tabular}{|c|c|c|c|c|}
\hline \multirow{2}{*}{ Year } & \multirow{2}{*}{$\begin{array}{c}\text { Undergra } \\
\text { duates }\end{array}$} & \multicolumn{2}{|c|}{ Postgraduates } & \multirow{2}{*}{$\begin{array}{c}\text { Doctoral } \\
\text { Students }\end{array}$} \\
\cline { 3 - 4 } & & Academic & Professional & \\
\hline 2004 & 178 & 62 & & 23 \\
\hline 2005 & 161 & 58 & & 27 \\
\hline 2006 & 173 & 64 & & 25 \\
\hline 2007 & 168 & 53 & & 24 \\
\hline 2008 & 153 & 57 & & 17 \\
\hline 2009 & 150 & 52 & 40 & 16 \\
\hline 2010 & 144 & 47 & 54 & 24 \\
\hline 2011 & 136 & 52 & 45 & 29 \\
\hline 2012 & 136 & 40 & 68 & 25 \\
\hline 2013 & 140 & 32 & 72 & 25 \\
\hline
\end{tabular}

Table 5. 2004-2013 the Number of GIS Graduates in Wuhan University

\begin{tabular}{|c|c|c|c|c|}
\hline \multirow{2}{*}{ Year } & \multirow{2}{*}{$\begin{array}{c}\text { Undergra } \\
\text { duates }\end{array}$} & \multicolumn{2}{|c|}{ Postgraduates } & \multirow{2}{*}{$\begin{array}{c}\text { Doctoral } \\
\text { Students }\end{array}$} \\
\cline { 3 - 4 } & & Academic & Professional & \\
\hline 2004 & 185 & 60 & & 7 \\
\hline 2005 & 155 & 65 & & 8 \\
\hline 2006 & 127 & 98 & & 23 \\
\hline 2007 & 117 & 51 & & 23 \\
\hline 2008 & 176 & 59 & & 19 \\
\hline 2009 & 150 & 45 & & 22 \\
\hline 2010 & 152 & 45 & & 18 \\
\hline 2011 & 157 & 41 & 39 & 18 \\
\hline 2012 & 134 & 34 & 51 & 14 \\
\hline 2013 & 144 & 46 & 45 & 17 \\
\hline
\end{tabular}

Data in Table 4 and Table 5 shows that the enrolments for undergraduates and academic postgraduates have a decreasing trend but the professional postgraduates increasing rapidly, and doctoral students is stable. The ratio of the undergraduates, postgraduates and doctoral students is roughly $3: 1: 0.4$. There are three main factors explaining the decreasing: First, GIS is not a popular major in China now. It is emerging and a large number of people know little about it. So the first choice rate in 
college entrance examination of students is not high (Tang Guoan, 2013). The second factor is the competition of similar majors. Because GIS is a comprehensive discipline related to earth sciences, mapping, remote sensing, computers, mathematics, management, etc., the curriculum often overlap or cross its predecessor's which would confuse students and make them choosing other similar majors. The third is related to the national enrolment policy. In recent years, Wuhan University undergraduate enrolments continued to shrink, in addition, the first choice rate of college entrance examination, the employment rate and other factors also affect the enrolments.

From the number of graduates, we see a slightly decrease in undergraduates and academic postgraduates. The number of

\subsubsection{The Classification of Graduates}

As shown in Figure 4, we see that the graduates' selection between study and work has changed a lot. First, the proportion of going on study as postgraduates increased with the increasing
Ph.D. graduates began to increase from 2006 and keep stable after that. Since 2009, the nation increased supportive strength by policy, through the methods of full-time training with double certificates, increasing the rate of enrolments and decreasing the length of schooling. The professional postgraduates become more and more popular for the above advantages. From here we see that the decreasing of the number of graduates is influenced by the decreasing of enrolments in the level of undergraduate. The decreasing of academic postgraduates is caused by the increasing of professional postgraduates. The number of Ph.D. graduates is stable because students are more independent and rational with deeper learning and more complete life planning when choosing the Doctoral Degree Program.

demand of high-level talents. It grew $16.78 \%$ from 2004 to 2013. Second, the proportion of studying abroad increased $11.41 \%$ in ten years. Third, the unemployment rate fell $9.45 \%$ in the decade owing to the job market expansion and high quality of our GIS graduates.

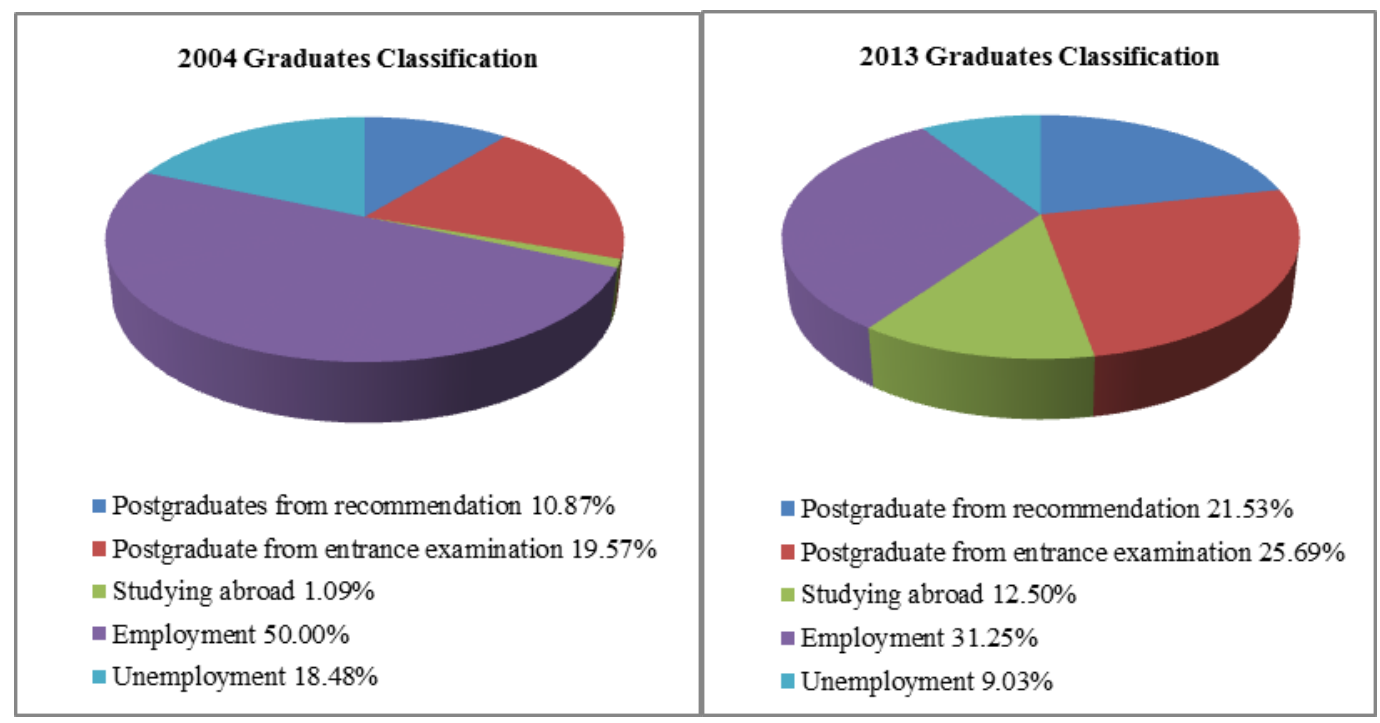

Figure 4. 2004/2013 Classification of Graduates with Bachelor's Degree

\subsubsection{The Industrial Distribution of Employers}

Figure 5 shows the industrial distribution of the graduates that went to work in the year 2004 and 2013. From it we see that graduates worked in government agencies and institutions dropped $24.28 \%$, worked in school drooped $6.47 \%$ and work in state-owned enterprises dropped $5.39 \%$. In contrast, more graduates choose going to companies, the percentage grew $37.22 \%$ in ten years. The number of going to army is almost unchangeable. The main factors contributing to this change are: First, government agencies, institutions, schools, and stateowned enterprises raised their threshold of entry. With the increase of talents with higher degrees, more units and departments tend to recruit person with Master's or Doctoral degrees, graduates with Bachelor's degree are excluded. Second, the rapid development of GIS enterprises provides a large number of job opportunities for graduates in recent ten years. More students would like to work in these enterprises. 


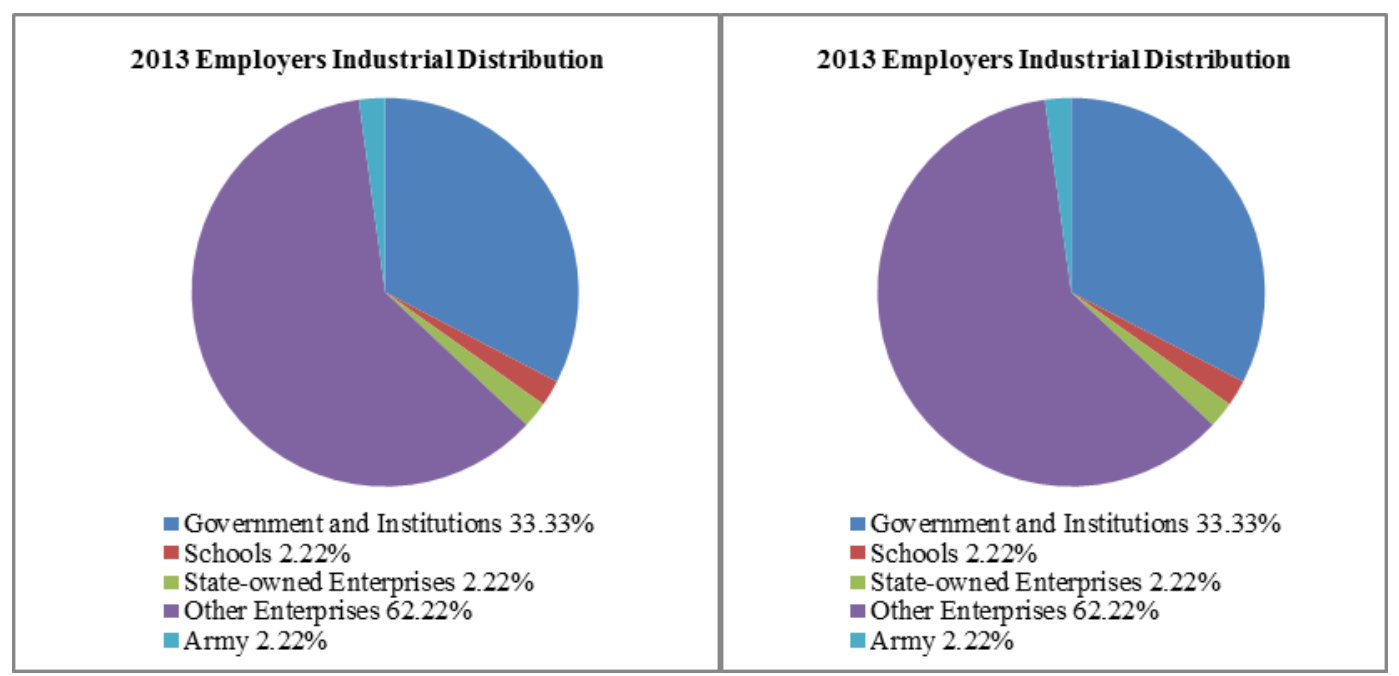

Figure5. 2004/2013 Industrial Distribution of Employers

\subsubsection{The Regional Distribution of Employers}

From the regional distribution of graduates as shown in Figure 6 , the graduates spread to 25 provinces and cities in 2004 , but reduced to 20 provinces and cities in 2013. There are no graduates in Anhui, Tibet and Ningxia both in the year of 2004 and 2013. The top three provinces of graduates' number are Hubei, Guangdong and Beijing in 2004, and the top three are also Hubei, Guangdong and Beijing (Liaoning tied) in 2013. As can be seen from the figure, nearly $1 / 4-1 / 5$ graduates went to the central region, which is the Wuhan University located area with more local students. Economically advanced North, East and South attracted most of the graduates, and only about 10 per cent of the graduates going to not economically advanced Southwest and Northwest. Besides, the graduates in Northeast increased a lot in recent years. Obviously, the regional distribution of graduates is affected by the factors of their Alma Mater and economy.

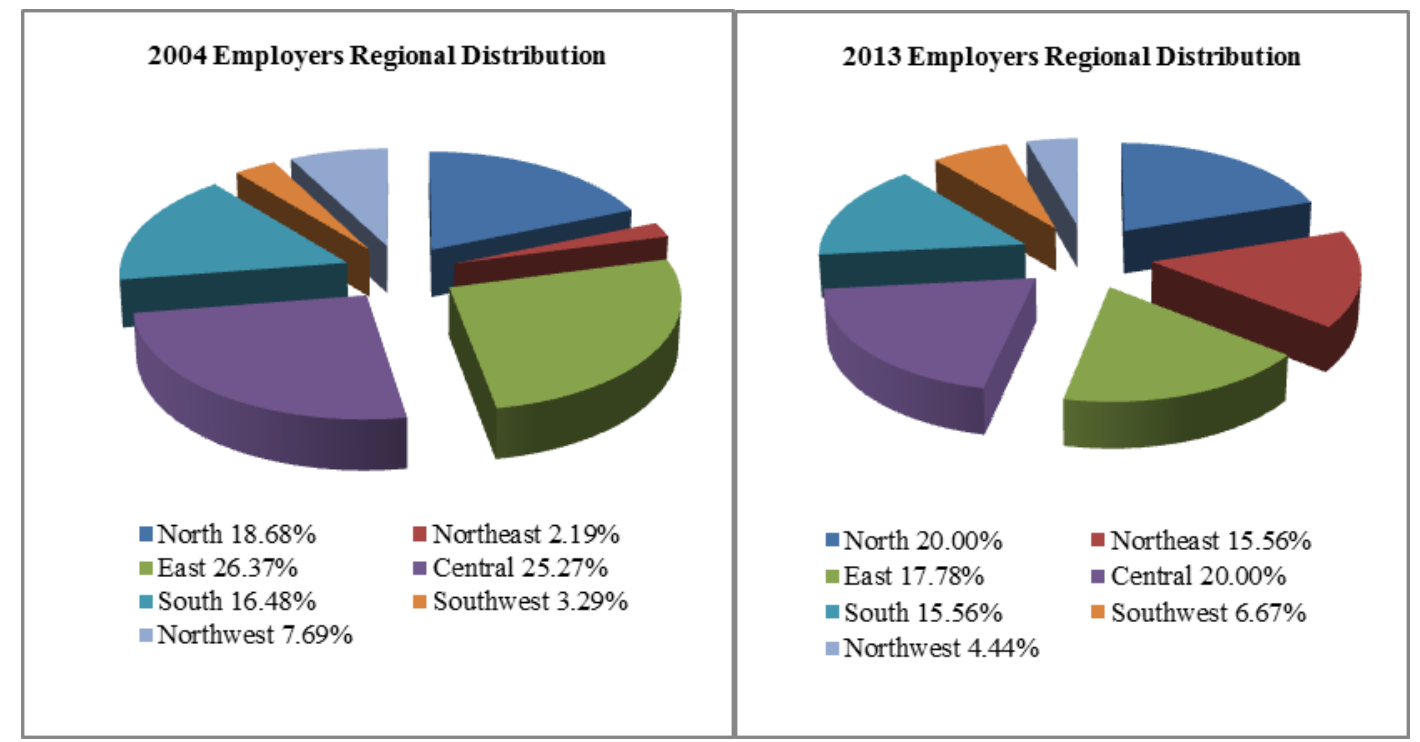

Figure 6. 2004/2013 Regional Distribution of Employers

\section{CONCLUSION}

Through the above analysis, the advantages of our current GIS education are the large scale colleges and universities, diversified developing forms and reasonable design of curriculum. But there are also many problems on the other hand, such as the uneven distribution, the unbalance between the teaching content and market demands and so on. This requires us to make better plans in accordance with the professional orientation and training objectives, and constantly revise the curriculum, enhance the teaching power, strengthen international cooperation and exchanges, trying to cultivate the talents of high qualities who meet the new age's needs and intense competition.

\section{References}

Bian Fuling., 2004. GIS Higher Education in China: Progress, Features and Research. Geographic Information World, 10, pp.16-22. 
Bian Fuling., 2007. GIS Higher Education in China: Problems, Innovation and Development. Geographic Information World, 04, pp. 4-8.

Jia Zelu, Liu Yaolin,2006, Teaching reform of GIS Specialization from employment point of view in China, Geospatial information.

Liu Yaolin, Liu Yanfang, 2003, Optimising design of Curriculum of GIS Specialization. World of Geo-information.

Qin Qiming, Dong Tingxu., 2011. Discussion on GIS Higher Education Development in China. Chinese University Teaching, 05, pp. 34-37.

Tang Guoan, Dong Youfu, Tang Wanrong, Li Xin., 2013. Investigation and Analysis for China's GIS higher education, China University Teaching, 06, pp. 26-31. 